\title{
EXAMPLES OF APPLICATIONS OF GEOTHERMAL WATERS FOR RECREATION, HEATING AND BOTTLING IN SELECTED REGIONS OF HUNGARY
}

\section{Elżbieta HAŁAJ \& Anna WACHOWICZ-PYZIK}

\author{
AGH University of Science and Technology, Faculty of Geology, \\ Geophysics and Environmental Protection, Department of Fossil Fuels; \\ al. Mickiewicza 30, 30-059 Krakow, Poland; \\ e-mail: elzbieta.halaj@gmail.com,amwachow@gmail.com
}

\begin{abstract}
Due to the favourable geothermal conditions in Hungary, where the geothermal gradient is about 1.5 times greater than the world average, the country has numerous centers, which use geothermal waters directly for heating, recreation, or bottling purposes. There are plenty of thermal and mineral water springs, most of which were known even 4000 years ago. This article presents different applications of geothermal waters, illustrated with examples of spas, recreation and balneology centers like the largest spa complexes in Europe - Széchenyi Spa and 500 years old Rudas Spa located in Budapest, Egerszalók with unique travertine deposit or Miscolctapolca in the area of Miskolc where a thermal karstic cave system originally carved and dissolved by the water in karstified Triassic limestone was transformed into a complex of geothermal swimming pools. The dynamic development of the geothermal energy uses system in Veresegyház, which total installed thermal capacity is nearly $13 \mathrm{MW}$ with the total track length of $15 \mathrm{~km}$ geothermal pipe line, classify the Veresegyház as one of the most extended geothermal systems in Hungary.
\end{abstract}

Key words: geothermal energy, geothermal waters, geothermal recreation, mineral waters, Hungary

\section{INTRODUCTION}

There are favourable geothermal conditions in Hungary. The geothermal gradient is $5^{\circ} \mathrm{C} / 100 \mathrm{~m}$ - about 1.5 times greater than the world average. The measured values of thermal flux reach approximately $90 \mathrm{~mW} / \mathrm{m}^{2}$. Such excellent conditions are related to low 
thickness of the Earth crust in the Pannonian basin (about 24-26 km) and types of rock well insulating clayey and sandy sediments (Csáki et al. 2006). The main geothermal reservoirs are hosted by the Upper Pannonian (Late Miocene) and Quaternary vast complexes of porous, permeable sand and sandstone formations and the Triassic carbonates with secondary porosity due to fracturing or karstification.

Surface manifestations like thermal springs in Budapest have been known since the Roman times (Toth 2010). In Hungary, water is classified as "thermal" if its temperature is higher than $30^{\circ} \mathrm{C}$ at the outflow from natural spring or well. Thermal water is accessible in about $75 \%$ country's territory. About $30 \%$ of the production wells deliver thermal water for balneological purposes, more than $25 \%$ supply drinking water, and about $50 \%$ are used for geothermal energy production (Csáki et al. 2006). The location and temperatures of the underground water in Hungarian geothermal wells are given in Figure 1. For balneotheraphy and recreation 289 wells and 120 natural springs are used (Toth 2010), respectively.

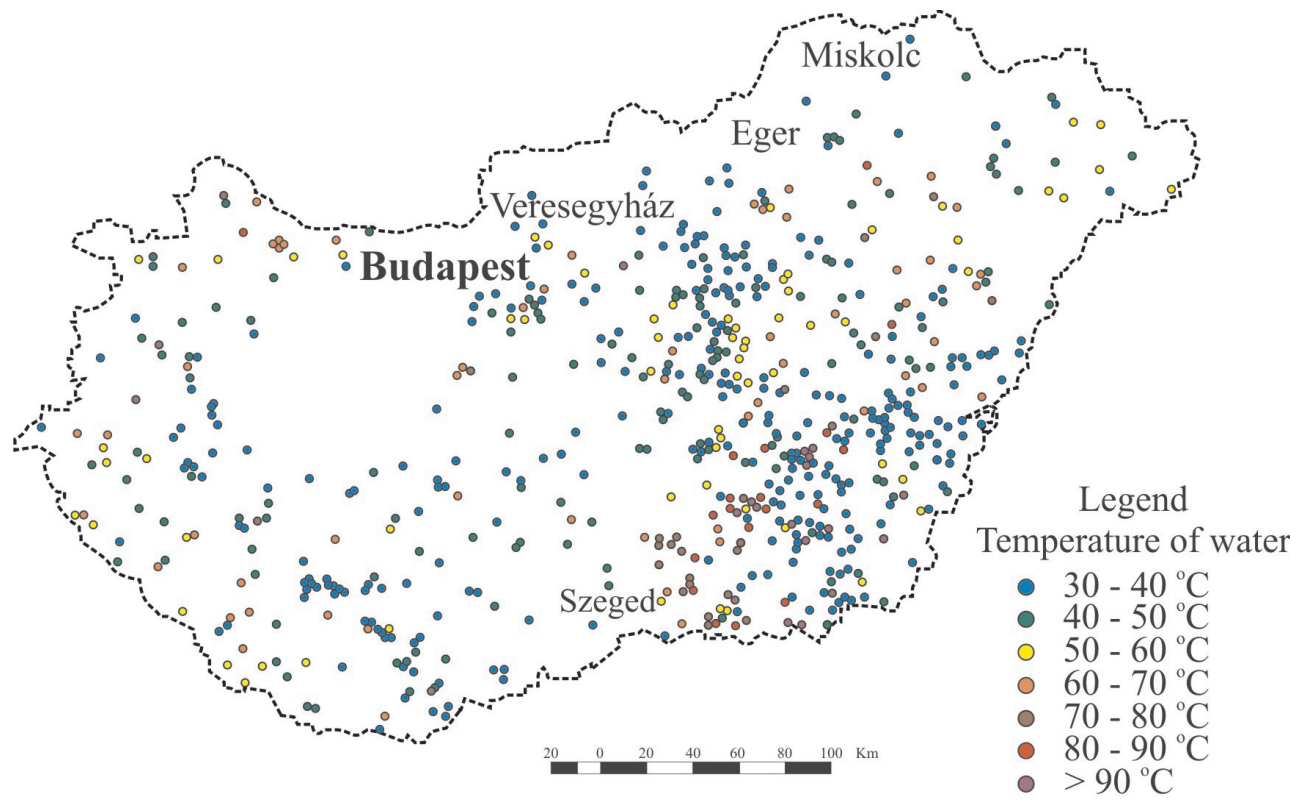

Fig. 1. Temperatures of the water at the head from wells located in Hungary (based on Csáki et al. 2006)

\section{STUDY AREA FOR BALNEOLOGY IN HUNGARY}

Budapest, the capital of the country, has the most ancient thermal bathing culture in Hungary. The excavations have shown that the thermal springs were known there even 
about 4000 years ago. In the Stone Age, in the area of today Szent Gellért Hotel, water surface did not freeze in the winter, which made the Danube easier for people of the tribes living in the area to cross the river by boats.

In the Roman times bathing culture was very rich. In the area of Óbuda, a military camp Acquincum was set up, where civil and military baths were established $\left(2^{\text {nd }}-3^{\text {rd }}\right.$ c. A.D.), and later on the same springs served the Turkish bath during the Ottoman-Turkish occupation $\left(16^{\text {th }}-17^{\text {th }}\right.$ c. A.D.) (Gömör \& Mészáros 2008). After World War I, Hungary lost over two thirds of its territory and the majority of internationally known and well prospering spas got beyond the new borders. At that time, the development of the spas focused in the capital like Szent Lukács Spa, Széchenyi Spa and Szent Gellért Spa (Bender et al. 2008). Nowadays most of the Hungarian worldwide-known spas are located in Budapest, Bük, Hajdúszoboszló, Harkány, Hévíz, Sárvár, Zalakaros and in many other places (Toth 2010). Only in Budapest, there are 123 natural hot springs and wells, which provide 70 million litres of water ranging in temperature from $21^{\circ} \mathrm{C}$ to $78^{\circ} \mathrm{C}$ per day (Tarlós 2012).

\section{Széchenyi Spa and Swimming Pools - Budapest}

The Széchenyi Spa and Swimming Pools is one of the largest spa complexes in Europe. It was built between 1909 and 1913 in neo-renaissance style. Hot spring water is discharged from the depth of $1246 \mathrm{~m}$ by the Saint Stephen Well No. II commissioned in 1938. The characteristic chemical components of water are calcium, magnesium-hydrogen-carbonates, chloride, sulphates, alkalis and fluoride (Tarlós 2012). Temperature of the medicinal water at the wellhead is $76^{\circ} \mathrm{C}$; its chemical composition is shown in Table 1.

There are 15 indoor pools and 3 outdoor pools with different water temperatures $\left(18-40^{\circ} \mathrm{C}\right)$ in Széchenyi Spa and Swimming Pools Complex. Moreover, there are ten saunas and steam chambers. The total water surface in the Spa is $2711.9 \mathrm{~m}^{2}$. Apart from the Spa and swimming pool section the Széchenyi Spa and Swimming Pools offer a treatment unit hospital for day patients where insurance-supported medicinal treatments are also provided. This treatment includes bathing in medicinal water pools and tubs, mud-packs, sub-aqueous traction, bathing in carbonated water, medicinal and underwater jet massage, group exercises in water and other items of balneological care. Other services are available for additional fees (Tarlós 2012).

The bath in the geothermal water is recommended for degenerative joint diseases, chronic and sub-acute arthritis, orthopaedic and post-accident treatments (Tarlós 2012).

Apart from bathing, the water is also used for drinking as a medicinal cure. Treatment with drinking medicinal water is advisable for e.g. chronic gastric catarrh, gastric ulcer, hyperacidity, certain types of kidney stone diseases, the gouty disorders of the metabolism, prevention and treatment of the shortage of calcium in the osseous/bone system (Tarlós 2012). 
Table 1

Mineral composition of geothermal water in Egerszalók and Széchenyi Spa (Vízkutató Vízkémia Ltd. 2007, Tarlós 2012)

\begin{tabular}{|l|c|c|}
\hline \multirow{2}{*}{ Component } & \multicolumn{2}{|c|}{ Measured value $\left[\mathrm{mg} / \mathrm{dm}^{3}\right]$} \\
\cline { 2 - 3 } & Egerszalók & Széchenyi Spa \\
\hline $\mathrm{HBO}_{2}$ & 11.10 & 6.50 \\
\hline $\mathrm{H}_{2} \mathrm{SiO}_{3}$ & 50.00 & 36.40 \\
\hline $\mathrm{CO}_{2}$ & 328.00 & 375.50 \\
\hline Bound $\mathrm{CO}_{2}$ & 227.00 & - \\
\hline $\mathrm{K}^{+}$ & 11.10 & 21.40 \\
\hline $\mathrm{Na}^{+}$ & 64.00 & 176.20 \\
\hline $\mathrm{NH}_{4}{ }^{+}$ & 0.41 & \\
\hline $\mathrm{Ca}^{2+}$ & 154.00 & 156.30 \\
\hline $\mathrm{Mg}^{2+}$ & 22.60 & 35.00 \\
\hline $\mathrm{Fe}^{2+}$ & 0.08 & - \\
\hline $\mathrm{Mn}^{2+}$ & 0.00 & - \\
\hline $\mathrm{Li}^{+}$ & 0.21 & 0.20 \\
\hline $\mathrm{NO}_{3}{ }^{-}$ & $<1$ & - \\
\hline $\mathrm{NO}_{2}^{-}$ & 0.00 & - \\
\hline $\mathrm{Cl}^{-}$ & 29.00 & 197.00 \\
\hline $\mathrm{Br}^{-}$ & 0.18 & 0.20 \\
\hline $\mathrm{I}^{-}$ & 0.03 & 0.07 \\
\hline $\mathrm{F}^{-}$ & 1.61 & 2.75 \\
\hline $\mathrm{SO}_{4}{ }^{2-}$ & 71.00 & 211.20 \\
\hline $\mathrm{HCO}_{3}{ }^{-}$ & 628.00 & 554.60 \\
\hline $\mathrm{S}^{2-}$ & 3.50 & 1.21 \\
\hline $\mathrm{PO}_{4}{ }^{3-}$ & 0.00 & - \\
\hline $\mathrm{Total}^{-}$ & 1602.00 & \\
\hline
\end{tabular}

\section{Rudas Spa and Swimming Pools - Budapest}

The central part of the Spa - an octagonal pool, which is located under the columnsupported dome - was built during the Turkish occupation in $16^{\text {th }}$ century. This 500 -year old Spa is called "Turkish baths". The thermal Spa has been opened only for men from 1936. After the reconstruction works in 2005 the Spa is also opened for women on Tuesdays and at weekends. The total water surface is $382 \mathrm{~m}^{2}$. The Spa offers five medicinal $\left(28-42^{\circ} \mathrm{C}\right)$ and one immersion pool $\left(16^{\circ} \mathrm{C}\right)$ in a Spa section and an indoor swimming pool, where the water has temperature of $29^{\circ} \mathrm{C}$. Radioactive medicinal water contains sodium, calcium-magnesium-hydrogen-carbonates, sulphates and fluoride. Treatment includes 
bathing in medicinal water pools and tubs, medicinal and underwater jet massages. Other massages are available for additional fees (Tarlós 2012).

Therapeutic recommendations for the water are e.g. degenerative diseases of the joints, chronic and semi-chronic inflammation of the joints, protruded intervertebral disc (Tarlós 2012).

The Rudas Fürdő (Spa) is supplied mainly by three famous springs, one of them is Juventus. Water coming from Juventus is applied for bath serving as a rejuvenation, which also indicates the name of the springs. As drinking water, it is used by those who suffer from disorders of kidney, gall bladder and digestive system (Tarlós 2012).

\section{Egerszalók}

Egerszalók is a village between Eger and Demjén, near the Bükk Mts. in the valley of the Laskó-creek. Medicinal water in Egerszalók area has been used for bathing and curing in some spas and resorts. The water comes from two wells drilled in 1961 and 1987 as oilexploration boreholes. Drillings reached geothermal water in confined Mesozoic - Tetriary reservoir, which is under artesian conditions (Kele et al. 2008). The first well (De-42) was adopted to water supply well. Water has temperature of $65^{\circ} \mathrm{C}$ and static water level reaches $+30 \mathrm{~m}$. Well has screening from $397.5 \mathrm{~m}$ down to $403.5 \mathrm{~m}$ and its bottom is at $407.5 \mathrm{~m}$ depth. The second well (De-42/A) was drilled $15 \mathrm{~m}$ east from the De-42 well, its yield has been strongly decreasing. The depth of the new well is $426 \mathrm{~m}$ and the temperature of explored water is $68^{\circ} \mathrm{C}$. The yield of the water is higher by $700 \mathrm{l} / \mathrm{min}$ comparing to the De-42 well. Recently the De-42/A well started to supply the spa hotel (Gondár-Söregi 2012).

The calcium-magnesium-bicarbonate type thermal water with a significant content of sodium and metasilicic acid has been ranked as one of the best in the sulphuric medicinal waters category. 19 from 30 of the water trace elements are biologically essential. In 1992 the water was classified by the Hungarian Ministry of Health as having therapeutic features (Vízkutató Vízkémia Ltd. 2007).

Currently the water is recommended for degenerative musculoskeletal disorders: arthrosis, back and lower back pain, non-acute stages of inflammatory musculoskeletal disorders, inflammatory gynecological diseases, psoriasis, eczema (Vízkutató Vízkémia Ltd. 2007). Contraindications: severe cardiovascular diseases, fever and infectious diseases, skin lesions, malignant tumours, incontinence (Vízkutató Vízkémia Ltd. 2007).

The total dissolved mineral content is $1602 \mathrm{mg} / \mathrm{dm}^{3}$. The mineral composition of the water is shown in Table 1.

The Egerszalók Travertine (Fig. 2) called Hungarian Pamukkale (from travertine site in Asiatic side of Turkey) or just "Salt Hill" is one of the most unique and spectacular travertine sites in Central Europe (Vízkutató Vízkémia Ltd. 2007). The Egerszalók Travertine deposit is classified as spring-mound, which is similar to the famous Pamukkale travertine in Turkey and Mammoth Hot Springs deposits at Yellowstone National Park (Kele et al. 2008). 


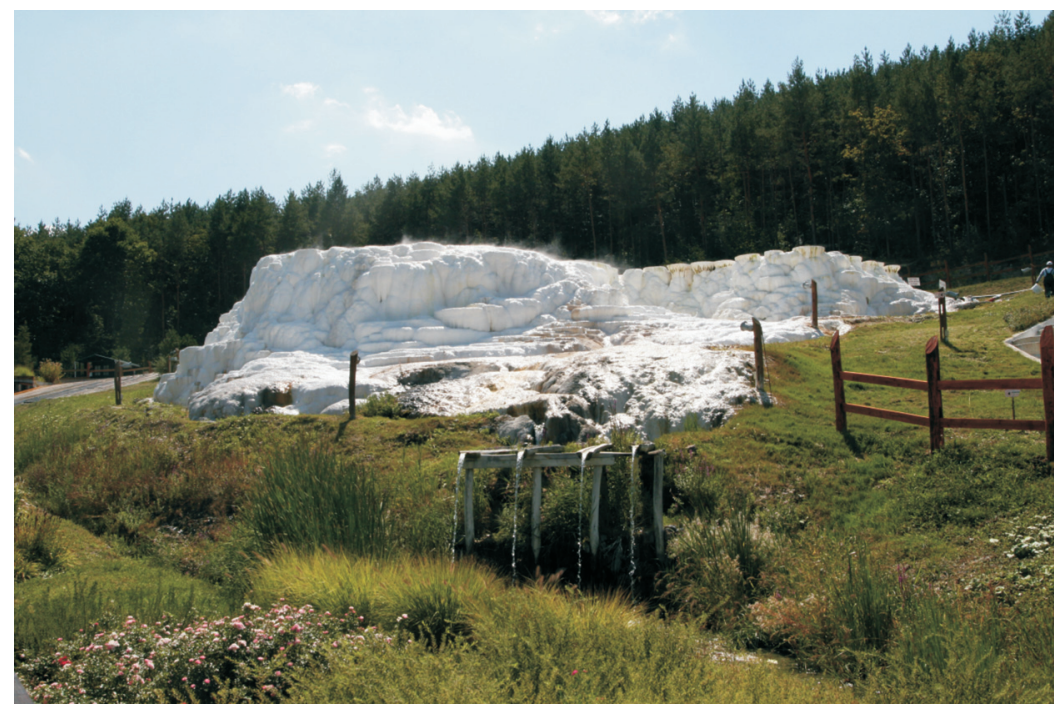

Fig. 2. The Travertine in Egerszalók precipitated from geothermal water

Travertine is actively precipitating from the discharged thermal water. It is formed at the output of wells. The travertine mound was $40 \mathrm{~m}$ long and about $8 \mathrm{~m}$ high in 2008 (Kele et al. 2008). The reservoir rocks consists mostly of the Middle to Upper Triassic and the Upper Eocene limestones - karstified rocks with very high permeablility. The Egerszalók Travertine is located in the drainage area of Maklány-Valley where bedrock is mostly composed of the Upper Triassic limestones (the Berva Limestone Formation), the Upper Eocene Szépvölgyi Limestone Formation, the Buda Marl Formation and the Lower Oligocene claymarl, sandstone and manganiferous clay-marl of the Tardi Clay Formation. In Egerszalók area, the Mesozoic carbonate suite covered by the Paleogene rocks is faulted and overlain by several hundred meters of the Neogene volcanic rocks. The karstic thermal water discharges around the mountains in several natural springs and numerous artificial wells (Kele et al. 2008). While water cools down and flows along the well on the slopes of the hill, it loses $\mathrm{CO}_{2}$ component and forms travertine cone (Gondár-Söregi 2012).

The research done in Egerszalók showed that water temperature in the aquifer is about $70^{\circ} \mathrm{C}$ and its age based on ${ }^{14} \mathrm{C}$ data is approximately 13200 years. The water at the vent has slightly acidic $\left(\mathrm{pH}=6.1\right.$ ), which is caused by significant amount of dissolved $\mathrm{CO}_{2}$. The discharging waters have also high concentrations of $\mathrm{Ca}, \mathrm{Na}, \mathrm{Mg}$ and $\mathrm{HCO}_{3}^{-}$(Kele et al. 2008).

\section{Miskolctapolca}

Miskolctapolca is a resort of Miskolc. The most precious natural treasure of the area is located there: a thermal karstic cave system - originally carved and dissolved by the water 
in karstified Triassic limestone - transformed to the Cave Bath in 1950's. Thermal spring is a significant karstic hot spring with $\mathrm{Ca}-\mathrm{Mg}-\mathrm{HCO}_{3}$ type water. The water has a temperature between $24-31^{\circ} \mathrm{C}$ (Mádai 2010). Previously, several thermal springs occurred in the area of the Cave Spa. About the water temperature was in the range $30-32^{\circ} \mathrm{C}$ in the warmest spring and $11-17^{\circ} \mathrm{C}$ in the coldest one (Gondár-Söregi 2012). Exploitation of springs for the needs of spa caused changes in springs' original rising location and nowadays, springs cannot be found on surface. All the water is chanelled artificially (Mádai 2010).

The Cave Spa is located east of the Bükk Mountains, at the boundary between the Triassic limestones (the Bükkfennsík Limestone Formation and the Répáshuta Limestone Formation) and the Miocene-age clastic sedimentary rocks (the Egyházasgerge Formation). The difference in pressure of karstic water level between the uplifted reservoirs in the Bükk Mountains and the buried reservoirs, which is about 40 bars, forces the karstic cold water underneath the thick complex of clastic sediments and forms a regional confined aquifer. The karstic water heats up at a depth of a hundred to a few thousand meters, migrates along faults and occurs at the surface as tepid or warm thermal springs (Mádai 2010). The latest investigations showed that its ${ }^{13} \mathrm{C}$-corrected radiocarbon age is $900 \pm 200$ years (Gondár-Sőregi 2012).

The rate of precipitation in Miskolctapolca Cave Bath is very high ranging from 1 to even $10 \mathrm{~mm} /$ year, which is at least $10-15$ time higher than the rate of precipitation in cold atmosphere caves. This high precipitation builds up $2-4 \mathrm{~cm}$ wide tetarata rows, stalactites, straws, stalagmites. Red ferric precipitations and yellowish brown dripstones can be seen as well as "lamp-flora" - algae with a few filaments of moss. Some technical equipment (cables, piping, etc) is also rapidly covered by calcite. In the underwater cave located in a well with 3-meter diameter and more than 30-meter deep some well-developed calcite crystals occur. Apart from precipitation, dissolution processes operate that result in karst features like domes, chimneys etc. (Mádai 2010).

\section{DISCUSSION \\ ON THE GEOTHERMAL DISTRICT HEATING SYSTEM IN VERESEGYHÁZ}

Thanks to the favourable geothermal conditions in Hungary, the country has numerous facilities, which use geothermal energy direct for heating individual facilities and buildings of public utility. As a priority, geothermal energy is used in several cities like Kapuvár, Mosonmagyaróvár, Vasvár, Nagyatád, Veresegyház, Jászkisér, Szolnok, Szarvas, Csongrád, Szentes, Hódmezővásárhely, Szeged and Makó. With the financial assistance from EU funds, under the Environment and Energy Operational Programme, the Hungarian government supports projects aimed at using renewable energy sources. Depending on the investor, and taking into account the project costs and the effectiveness of development, geothermal investments can rely on subsidies (Szita 2012). 
One of the largest geothermal heating systems in Hungary is located in Veresegyház in the northern part of the country, about $22 \mathrm{~km}$ from Budapest. The total installed thermal capacity of the system is nearly $13 \mathrm{MW}$. The geothermal energy provides about $74 \mathrm{TJ}$ annually, what leads to saving almost 2.2 million $\mathrm{m}^{3}$ natural gas per year. The geothermal system is used for heating and domestic hot water purposes. The expansion project of the system received EU funding twice, and cooperation with the Hungarian government positively influenced the project (Szita \& Vitai 2012).

The first borehole B-15 was drilled in 1987 . Initially, a $64^{\circ} \mathrm{C}$ water discharged by the well was used only for local spa purposes. Over the years, using geothermal energy for heating and domestic hot water for public buildings was started. The first object, which began to use geothermal heating in 1993 was Fabriczius Grammar School. In the following years the system grew with new customers. Since 2003, geothermal energy has been supplied to other school with a swimming pool and gym (Szita \& Vitai 2012).

The dynamic development of the geothermal energy application by system in Veresegyház has resulted in new wells. Thanks to the EU funding, a construction of re-injection well was completed. The construction of a new borehole was associated with the thermal water re-injection law, which has been applied on the territory of Hungary since 2004 (Szita \& Vitai 2012).

In response to the growing demand for energy, the authorities of Veresegyház requested further funding for the project. Within the programme, a second production well was completed, a new pump station was expanded, and $6.6 \mathrm{~km}$ pipelines were laid making possible that now the geothermal system can be used not only by local public institutions but also factories (a pharmaceutical company, an electricity network design and installation company and a sewing company). Currently, the system is using two production wells. First well B-15 has a total depth of $1462 \mathrm{~m}$ and temperature of $65.5^{\circ} \mathrm{C}$ in the water reservoir. Second well $\mathrm{K}-25$ constructed in 2011, with a depth of $1202 \mathrm{~m}$ and the temperature of $63.7^{\circ} \mathrm{C}$ in the reservoir. In a re-injection well K-23, made in 2006, the injection water has temperature of $38^{\circ} \mathrm{C}$ (Szita \& Vitai 2012). Detailed information about wells is presented in Table 2.

Generally, geothermal reservoir of Veresegyház is built of karst limestone, mainly of Triassic and Eocene limestone and marl at the top. The reservoir temperature varies between $68^{\circ} \mathrm{C}$ and $70^{\circ} \mathrm{C}$ and the outlet temperature is about $64^{\circ} \mathrm{C}$. The annual production capacity of thermal water for the system is nearly $780000 \mathrm{~m}^{3}$ (Szita \&Vitai 2012). Water used for bathing spa facilities is not re-injected into the formation, and injection well during the summer does not work because the water is used only for hot domestic water production and then goes to spa (Szita \&Vitai 2012).

At present the city - in cooperation with Porció Ltd., which has actively participated in the project from the beginning - is planning a further expansion of the system. The next step is to connect individual customers (the city residents) to the heating network. If they succeed, it will be the first that kind system functioning in Hungary. Additionally, Porció Ltd. company in cooperation with the city, conducted a preliminary calculation, which assumption is to cover half of the total the city energy demand from geothermal source. On the 
basis of the results, they estimated that the other two production wells and one re-injection well will be needed. Attention should be drawn to the fact that so far, thanks to the investment in the systems, the emission of harmful gases - such as $\mathrm{CO}_{2}, \mathrm{NO}_{\mathrm{x}}$ and $\mathrm{SO}_{2}$, produced by conventional energy sources like coal, oil or natural gas - has been reduced; $\mathrm{CO}_{2}$ has been cut by $2.125 \mathrm{Mg} /$ year, $\mathrm{NO}_{\mathrm{x}}$ by $2838 \mathrm{~kg} /$ year and $\mathrm{SO}_{2}$ by $214 \mathrm{~kg} /$ year. This proves that the system is environmentally-friendly, as it substantially helps reducing emission of pollutants (Szita \& Vitai 2012).

\section{Table 2}

Well data of boreholes used in geothermal system in Veresegyház (Szita \& Vitai 2012)

\begin{tabular}{|c|c|c|}
\hline \multirow{2}{*}{ Parameters } & \multicolumn{2}{|c|}{ Production wells } \\
\hline & B-15 & K-25 \\
\hline Year of drilling & 1987 & 2011 \\
\hline Total depth [m] & 1462 & 1202 \\
\hline Screen $[\mathrm{m}]$ & $\begin{array}{c}1414-1457 \\
(1 \text { section) }\end{array}$ & $\begin{array}{l}1126-1202 \\
\text { (6 sections) }\end{array}$ \\
\hline Outflow water temperature $\left[{ }^{\circ} \mathrm{C}\right]$ & 65.5 & 63.7 \\
\hline Bottom hole temperature $\left[{ }^{\circ} \mathrm{C}\right]$ & 69.7 & 67.9 \\
\hline Flow rate $\left[\mathrm{m}^{3} / \mathrm{h}\right]$ & 66 & 72 \\
\hline Water reservoir & Triassic & Triassic, Eocene \\
\hline Parameters & \multicolumn{2}{|c|}{ Injection well K-23 } \\
\hline Year of drilling & \multicolumn{2}{|c|}{2006} \\
\hline Total depth [m] & \multicolumn{2}{|c|}{1600} \\
\hline Screen $[\mathrm{m}]$ & \multicolumn{2}{|c|}{$1310-1403$ (3 sections) } \\
\hline Average injection temperature $\left[{ }^{\circ} \mathrm{C}\right]$ & \multicolumn{2}{|c|}{38} \\
\hline Production water temperature $\left[{ }^{\circ} \mathrm{C}\right]$ & \multicolumn{2}{|c|}{64} \\
\hline Bottom hole temperature $\left[{ }^{\circ} \mathrm{C}\right]$ & \multicolumn{2}{|c|}{67.9} \\
\hline Production capacity $\left[\mathrm{m}^{3} / \mathrm{h}\right]$ & \multicolumn{2}{|c|}{94} \\
\hline Water reservoir & \multicolumn{2}{|c|}{ Triassic } \\
\hline
\end{tabular}

\section{DISCUSSION ON UTILIZATION AND BOTLLING WATER IN HUNGARY}

Until recently, mineral water in Hungary was defined as water whose 1 liter contained more than $1000 \mathrm{mg}$ of dissolved mineral elements, or in which the content of specific bioactive components exceeded the limits specified by the legislation. Currently, according 
to the changes implemented by the promulgation of the Joint Decree 65/2004 for bottling mineral water with enriched content and flavoured water in accordance with the European Council Directive 80/777/EEC, mineral water is not determined by any of the acceptable standards, which enabled to classify the type of mineral waters, both by the content of minerals and organic matter (Csáki et al. 2006).

Hungary has identified 135 medicinal water intakes for bath and 14 for consumption. Hungarian mineral waters have a long history and tradition of uses, so most of them are well known also at foreign markets. The worldwide recognized brands of Hungarian natural mineral and medicinal waters are for instance: Ferenc József, Mira, Parádi, Jodaqua, Salvus and Hunyadi János, which is available for example in some pharmacies and herbal stores in Poland. Chemical composition and mineralization of natural mineral and medicinal waters are presented in Table 3 (Korcsog 2012).

Table 3

Hungarian natural mineral and medicinal waters - chemical characteristic (Korcsog 2012)

\begin{tabular}{|c|c|c|c|c|c|c|c|}
\hline \multirow{2}{*}{$\begin{array}{c}\text { Water } \\
\text { brand name }\end{array}$} & \multicolumn{7}{|c|}{ Natural mineral } \\
\hline & $\begin{array}{c}\text { TDS } \\
{\left[\mathrm{mg} / \mathrm{dm}^{3}\right]}\end{array}$ & $\begin{array}{c}\mathrm{Ca}^{2+} \\
{\left[\mathrm{mg} / \mathrm{dm}^{3}\right]}\end{array}$ & $\begin{array}{c}\mathrm{Mg}^{2+} \\
{\left[\mathrm{mg} / \mathrm{dm}^{3}\right]}\end{array}$ & $\begin{array}{c}\mathrm{Na}^{+} \\
{\left[\mathrm{mg} / \mathrm{dm}^{3}\right]}\end{array}$ & $\begin{array}{c}\mathrm{Cl}^{-} \\
{\left[\mathrm{mg} / \mathrm{dm}^{3}\right]}\end{array}$ & $\begin{array}{c}\mathrm{SO}_{4}{ }^{2-} \\
{\left[\mathrm{mg} / \mathrm{dm}^{3}\right]}\end{array}$ & $\begin{array}{c}\mathrm{HCO}_{3}^{-} \\
{\left[\mathrm{mg} / \mathrm{dm}^{3}\right]}\end{array}$ \\
\hline Jodaqua* & - & 202 & 62 & 6700 & 10520 & - & 348 \\
\hline Salvus* & 22989 & - & - & 7308 & 2350 & - & 13913 \\
\hline Hunyadi János & 31243 & 364 & 2900 & 4700 & 700 & 21200 & 1210 \\
\hline Ferenc József & 20882 & 372 & 1555 & 3800 & 450 & 14500 & 567 \\
\hline Mira & 17565 & 230 & 496 & 4800 & 2700 & 8060 & 1226 \\
\hline Parádi & 4445 & 174 & 50 & 470 & 47 & 144 & 1780 \\
\hline Balfi & 1890 & 167 & 52 & 186 & 69 & 40 & 1275 \\
\hline Theodora Kékkúti & 1600 & 280 & 57 & 37 & 17 & 38 & 1110 \\
\hline Theodora Kereki & 904 & 144 & 34.4 & 32 & 16 & 144 & 487 \\
\hline
\end{tabular}

* thermal water

Particular attention should be drawn to two types of water: Jodaqua, which has unusually high quantity of iodides $\left(100 \mathrm{mg} / \mathrm{dm}^{3}\right)$ and bromides $\left(115 \mathrm{mg} / \mathrm{dm}^{3}\right)$ and Parádi with high amount of sulphate $\left(6.2 \mathrm{mg} / \mathrm{dm}^{3}\right)$. Two types of water listed in Table 3: Salvus and Jodaqua can be considered as geothermal waters. Also, the waters, which are available under the labels of well-known brands such as Nestlé Aquamineral use the springs of mineral waters in Hungary (Korcsog 2012).

Taking into account the list of natural mineral waters recognized by EU Member States in accordance with Article 1 of Directive 2009/54/EC of the European Parliament and of 
the Council of 18 June 2009 on the exploitation and marketing of natural mineral waters it is clear that Hungary is a country characterized by relatively high number (174) of water recognized as mineral water by comparison with other Member States (Fig. 3).

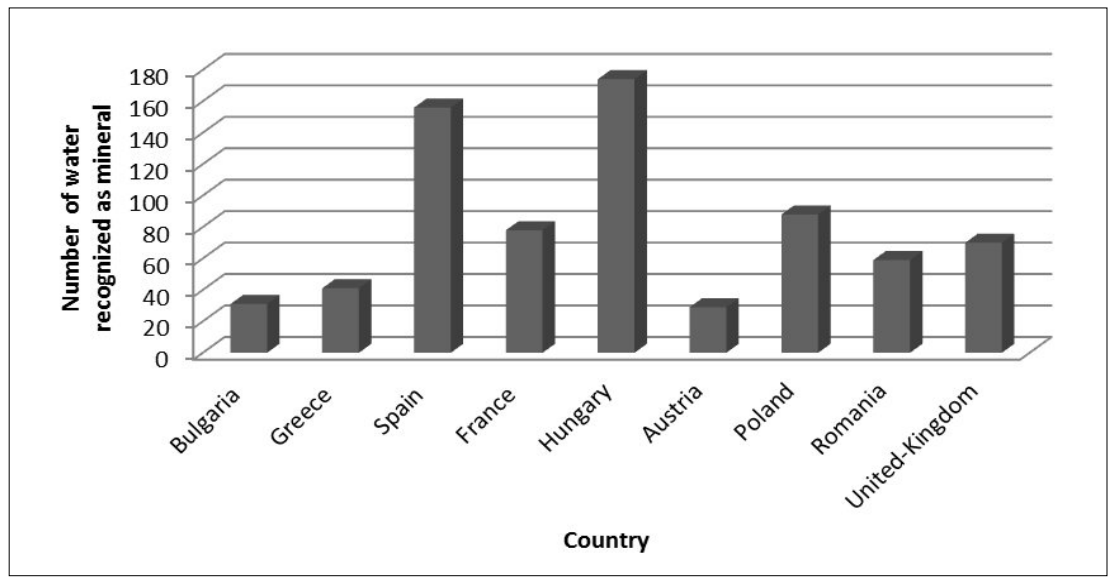

Fig. 3. The amount of natural mineral waters recognised in selected EU Member States (based on List of natural mineral waters recognized by Member States, 2012)

Considering the demand for water and favourable hydrogeological conditions in Hungary, a large increase in the Hungarian bottled water market is observed: only in 2011 there were 813301336 bottles of water produced in Hungary (Korcsog 2012), which is an increase of $34 \%$ by comparison with year 2006 .

\section{CONCLUSIONS}

Hungary gives excellent example of the geothermal energy use for various applications. As demonstrated in this article, Hungary utilizes its significant geothermal potential not only for heating but also for recreation or bottling water purposes. This is evidenced by numerous recreation centers, well-known both in Hungary and in foreign countries. Equally popular are the Hungarian drinking waters, which are also available in some of the European countries. Relatively significant share of thermal energy produced from geothermal resources classifies Hungary among top countries in Europe. It should be pointed out that the rapid development in the renewable energy sector in Hungary is associated with the participation, and involvement of the Hungarian government, in new investments related also to geothermal energy and its role in energy strategy, which is evidenced by e.g. the role of geothermal energy in NREAPs (National Renewable Energy Action Plans) i.e. ca. $6 \%$ in final total energy use in 2020 . 
This article was inspired by the IAH-CMTW Meeting 2012 held in Budapest, Hungary (August 2012).

The authors would like to thank Mr István Fórizs, Mrs Zsuzsanna Vitai, and Mr Attila Korcsog for all help in preparing this article and providing data. Thanks go also to GeoSynoptics Association "GEOS" for financial support given to authors, which enabled them to attend the event.

\section{REFERENCES}

Bender T., Kovács I., Gaál J. \& Tefner I., 2008. Balneology research in Hungary. Press Therm Climat, 145, 191-200.

Csáki F., Chikán A., Dura G., Horváth Z., Liebe P., Németh T. \& Pálmai O. (eds), 2006. Guide. Groundwaters in Hungary II. Ministry for Environment and Water, Budapest.

Directive 2009/54/EC of the European Parliament and of the Council of 18 June 2009 on the exploitation and marketing of natural mineral waters. European Council Directive 80/777/EEC.

Gömör B. \& Mészáros G., 2008. History of Hungarian balneology. Press Therm Climat, $145,181-186$.

Gondár-Sőregi K., 2012. Hydrology of Bükk Mountains. Field trip guide. SMARAGD-GSH Ltd.

Kele S., Demény A., Siklósy Z., Németh T., Tóth M. \& Kovács M.B., 2008. Chemical and stable isotope composition of recent hot-water travertines and associated thermal waters, from Egerszalók, Hungary: Depositional facies and non-equilibrium fractionation. Sedimentary Geology, 211, 3-4, 53-72.

Korcsog A., 2012. Short introduction of the Hungarian natural and medicinal waters, and the bottled water market. IAH-CMTW Meeting Budapest, Hungary, August 12-18 [electronic materials].

Lénárt L., 2010. The interaction of cold and warm karst systems in the Bükk region. Proceedings of the 1st Knowbridge Conference on Renewables. Miskolc, Hungary, September 27-28, 2010,University of Miskolc, Institute of Environmental Management, 109.

List of natural mineral waters recognized by Member States. Official Journal of the European Union 2012/C 83/01.

Mádai F., 2010. Minerals, history and wines - trip to Miskolc, Miskolctapolca and the Bükkalia region. Acta Mineralogica-Petrographica. Field Guide Series, 12, 1-12.

Szita G., 2012. New Direct Heat Geothermal Systems in Hungary. IGA NEWS Newsletter of the International Geothermal Association, 89, 4-5.

Szita G. \& Vitai Z., 2012. Geothermal energy utilization system in Veresegyház. IAH-CMTW Meeting Budapest, Hungary, August 12-18 [electronic materials].

Tarlós I., 2012. Budapest, the city of spas. Informational materials. [on-line:] www.spabudapest.hu.

Toth A., 2010. Hungary Country Update 2005-2009. Proceedings World Geothermal Congress 2010, Bali, Indonesia, 25-29 April 2010.

Vízkutató Vízkémia Ltd., 2007. Examination of medicinal water from Egerszalók Spa. 